\title{
Efforts to Maintain Javanese Language in the Middle of the Covid-19 Pandemic in the Surakarta Community, Central Java
}

\author{
Suharyo \\ Faculty of Humanities, Diponegoro University, Semarang
}

\begin{abstract}
In the XXI century, $50 \%$ of the world's regional languages will be extinct. Several experts are explaining that there are regional languages that become extinct every week. Does research need to be conducted to answer questions, such as how far can the Javanese language survive? What are the efforts? Does the covid-19 pandemic situation influence the preservation of the Javanese language? To answer these questions, this study uses observation and in-depth interviews. The results indicate that (1) Javanese Krama is almost extinct, (2) Javanese Ngoko still exists, (3) the existence of Javanese is threatened, (4) children (toddlers) have very little knowledge of Javanese. Meanwhile, strategies used to maintain the Javanese language through (a) education (formal and non-formal), (b) family networks, (c) continuing to teach children to speak Javanese, (c) through various competitions arts/culture (Kirab Budaya (Cultural Carnival), Geguritan, Macapatan, etc.), (d) through training (Gamelan, Karawitan, etc.), (e) exemplary from community leaders (Basa Tulodho), (f) via radio (RRI) and television through Javanese cultural shows (Wedangan, Klenengan, Kembang Setaman, etc.), (g) through printed media (Jawi book) containing Javanese norms/customs, (h) programs/policies from the Department of Tourism and Culture, (i) the Covid-19 pandemic affects the efforts made to maintain the Javanese language.
\end{abstract}

\section{Introduction}

Various Various literature explains that in Indonesia, there are 726 to 742 regional languages. Of these, "only" 13 languages are considered safe. The rest are categorized as less safe, endangered, and even extinct [1]. This is in line with UNESCO's prediction that the languages that exist in this world (estimated at 6,000 languages) will become extinct in the XXI century. If the extinction of a language occurs, it is actually not only linguistically extinct but also involves the extinction of the culture and civilization of the people who own the language. A situation that should not be left unchecked. According to [1], languages will become extinct if; (1) the influence of the majority language, (2) a bilingual/multilingual society, (3) the era of globalization, (4) population migration, (5) inter-ethnic marriages, (6) natural disasters, (7) lack of public respect for ethnic languages (regional languages), (8) lack of intensity in the use of regional languages as a means of communication in various domains, 
and (9) economic factors. In addition, there will be fewer local language speakers if; (a) the number of mass media / electronic media that use regional languages is very limited or even non-existent, (b) the development of social media, and (c) government policies towards the existence of regional languages.

The conditions and linguistic situations mentioned above also seem to occur in Javanesespeaking people, especially Surakarta. The Javanese language has begun to be abandoned by its speakers, especially by the younger generation [7]. From the observations that have been made, the children (toddlers) have not mastered Javanese, let alone Javanese Krama. They think that the Javanese language is "old fashioned", "not prestigious", "ndeso". Javanese is now only spoken by people, most of whom are over 40 years old. From various information and interviews, they still "miss" the Javanese language to remain in the social interaction system. However, the rapid flow of globalization is a necessity that cannot be avoided. Then, how do they try to defend it?

Still, they are trying to maintain the Javanese language through various strategies and/or efforts from the observations made. The effort they do is through; (a) formal and non-formal education channels, (b) through family networks, (c) arts and culture channels, and (4) media channels, and (5) local government policies. The next question is, how capable/effective are these steps/efforts? This paper will try to answer the question; (1) What language do they choose in their social interactions? (2) How are their efforts to defend the Javanese language? (3) How were these efforts carried out during the Covid-19 pandemic?

\section{Results and Discussion}

This paper must first mention the research methods/techniques, data collection, and analysis used before the research results are presented. Data collection was carried out using observation and in-depth interviews. Observation is applied to observe the use of everyday language in the people of Surakarta. Activities observed include household, neighbourly, and social interaction at the inter-RT / RW (neighbourhood association) level. Then, another method is in-depth interviews. In-depth interviews were conducted with several informants to dig further into the previous data extracted from observations. Interviews are also intended to triangulate data. The next stage is data analysis which is presented in section 2.1 below.

\subsection{Results}

Before Before describing the strategies/efforts of the people in Surakarta in maintaining Javanese during its competition with Indonesian and even with English, it is necessary to present the results of the language selection among the people in Surakarta. The result is; (a) Javanese Krama is almost extinct, (b) Javanese Ngoko is still quite widely spoken, (c) Indonesian has entered the home environment, (d) mixed languages (Indonesian and Javanese) have been used in neighbourhood and social environments, and (e) there is a tendency that children (toddlers) have not mastered the Javanese language.

In Joyosuran Village, Pasar Kliwon District, Surakarta, which is the research study area, according to observations and answers from an informant named Isni Susiloningsih (subdistrict employee): Javanese language defence has been carried out through various methods/strategies. The first strategy is through formal and non-formal education. In the teaching and learning process, educators still use Javanese, especially for children/students in grades 1 to 3 in elementary schools. He also suggested that Javanese subject hours need to be increased. Second, through a family environment strategy, which is implemented through Javanese, both Krama and Ngoko in the family/home environment. Third, through the transfer of the mother tongue to the next generation. Fourth, through cultural activities, primarily through the Kirab Budaya (Cultural Carnival) activity, which in this event, each village is asked to perform. Fifth, through Karawitan, namely Gamelan training events/activities held twice a week with participants, both teenagers and parents. Sixth, 
through the Geguritan and Macapatan competitions, which are participated by parents and adolescents (Karang Taruna). Seventh, through Klenengan, Kembang Setaman, and Javanese culture broadcast on Slank Radio. Eighth, through printed books about Jawi customs. Ninth, through TV and radio broadcasts such as traditional/cultural programs (for example, Wedangan), several television stations, such as Solo TV, MTA TV, and RRI. Tenth, through government programs/policies (Department of Culture and Tourism) and social institutions, such as the Kelompok Darwis (Tourism Awareness), holding various competitions.

Answers were obtained about Javanese language defence strategies when conducting interviews with other informants, such as Mrs Karsiati (a community leader). Mrs Karsiati said that efforts to maintain the Javanese language were carried out through; (1) family environment. According to Mrs Karsiati, family is the primary and first fortress in maintaining language (Javanese). Because the family is the "mother" of the Javanese language, suppose no one in the family speaks Javanese anymore. In that case, Javanese is only a matter of waiting for the death knell in the "womb" of the Javanese people themselves as the "mother" of the Javanese language; (2) social, environmental activities, such as Family Welfare Education Program (PKK). It is a tradition in society in this region that the language used in PKK meetings is mostly Javanese; (3) Javanese language training, such as the Pambiyoworo training, which is held once a month with participants in their $40 \mathrm{~s}$ on average; (4) celebration rituals and funeral processions; (5) non-formal education such as Early Childhood Education (PAUD), singing Javanese songs as often as possible using Javanese as the medium of instruction, (6) "Basa Tulodho", which is an example shown by the older generation through learning Javanese language (grammar and manners); (7) dance performance (in training) (for example the Gambyong dance); (8) Gamelan/Klenengan routine exercises (Sumodilagan group and Kusumolaras group).

From the results of field observations, it was found that; (1) Indonesian has begun to be used in the home environment and even in the social environment, (2) Javanese, especially Javanese Krama, is no longer mastered by children (under five), (3) mixed languages (Indonesian and Javanese) are already often used among the younger and middle generations (aged 30 years).

Efforts/strategies in maintaining the Javanese language that has been carried out have been hampered since the covid-19 pandemic. What appears to be constrained/affected are such as training (Klenengan / Gamelan, etc.), competitions (Geguritan, Macapatan, Kirab Budaya), while other activities were less constrained.

\subsection{Discussion}

Sibarani Sibarani explains that the form of culture consists of three, namely (a) ideas, (b) actions/activities, and (c) artefacts/works [6]. Of the three forms of culture, the form that most underlies the other two forms is the form of ideas. It is the idea that makes a society's culture more developed and vice versa. However, unfortunately, culture has so far been seen and even reduced so narrowly to just art [4]. Due to the lack of attention to aspects of ideas, for example, the concept / cultural data "aja dumeh" and "andhong", these two things have far-reaching implications, not just vocabulary/clusters of speech sounds: a-j-a-d-u-m-e-h; and a-n-d-h-o-n-g, but it has become a proposition. Culture (read: cultural heritage), according to Sedyawati [4], can be categorized into two categories, namely: (a) physical, cultural heritage, such as dance and music; and (b) non-physical culture (values, norms).

Judging from the cultural concepts above and their relation to the linguistic conditions in Javanese society, it is understandable why the Javanese language has begun to become less popular, especially in the younger generation. This is due to the Javanese language, which is a cultural product (non-physical) and a product of feudal culture (as a system of ideas) which is no longer appropriate to current conditions. This is also reinforced by the weakening role 
of "Javanese cultural centres", namely Yogyakarta and Surakarta [2, 4, 8]. Then, the Javanese language, as a social reality, is very dynamic so that it can develop, change, and even disappear [5]. Therefore, social change (read: the reality of the Javanese language) is undergoing change. This can be seen in social life, that the Javanese language has begun to get rid of by the Indonesian language. This is because the Javanese language is no longer used by children (toddlers) and the younger generation [7]. The social life of the Javanese community is also undergoing a shift (language) and a period of transition. This can be seen from the frequent use of mixed languages (Indonesian and Javanese) in their social interactions (household, neighbourhood, and social environment).

The current lack of popularity of the Javanese language is because the Javanese language is politically marginalized, namely since the Indonesian language was promulgated in the 1945 Constitution and strengthened by Law No. 24/2009. This further explains that the Indonesian language is the primary and first communication tool even though there have been various regional regulations to protect local languages from becoming extinct [9]. The condition of regional languages, including Javanese, worsens when devices have become a lifestyle for all levels of society. Gadgets (read: internet) are not only complementary to existing communication tools but have revolutionized the way people communicate. The internet has changed the way humans access information and has forced people to change the way of life (social interaction), change the structure of people's knowledge, and even change the value of life [5]. The internet has massively, structured, and systematically gripped people's cognition through the system of phonology, morphology, syntax (sentence structure), and lexicon. There is almost no room for the growth and development of regional languages on the internet because (almost) everything (lexicons and sentence structures) uses Indonesian and English. This condition causes the concept of a speech society to become fluid and "borderless" to be called a global speech society.

In the globalization that is plaguing all aspects of social life, including the people in Surakarta, it deserves thumbs up because even though they are "crushed" by various circumstances, they are still trying various strategies to maintain the Javanese language in the midst of its competition with Indonesian and English and the swift flow of globalization. They try to defend the Javanese language through (a) education, (b) family, (3) modelling, (4) competitions, (5) mass media, electronics, (6) print media, etc. However, it must be admitted that these efforts are currently hampered by the outbreak that is currently sweeping the world, namely Covid-19. The question is, how is the result? The following is quoted from the opinion of Rahyono [4].

"Culture from time to time is continuously created in a spiral. The world of life faced by humans demands the fulfilment of human needs. Human needs need to be met in order for humans to survive (live). In order to be able to survive, humans use their intellect, mind, and feelings to find ideas/ideas to create something relevant (according to the challenges/conditions of the times) with efforts to survive." Analogous to this quote with the preservation of language (Javanese) during a global situation like now, the Javanese people need to find ideas on how to keep the Javanese language alive through three cultural forms, namely: (a) ideas, (b) forms of activity, and (c) artefacts. So far, what has been done is only at the stage of activities and artefacts. This seems to be because the cultural perspective that is interpreted is still narrow, namely (only limited to) art, and has not touched the layers of ideas (world perspective). Therefore, the following quotes must become our reflections together [3-4]: 
1. The higher the quality of the living world faced by humans, the higher the survival rate one must have.

2. The higher the quality of the thinking / learning process carried out by humans in the creation of culture, the higher the quality of the ideas / ideas of cultural creation that are found.

3. The higher the quality of the cultural creation idea found, the higher the quality of the cultural representation or work created.

4. The higher the quality of the culture one has, the higher the quality of the process of sharing the culture that was created

Now, everything returns to the people in Surakarta, whether they will try their hardest with intelligence, wisdom, exemplary, and concrete steps to defend the Javanese language or, on the contrary, let the Javanese language slowly be swallowed up by time. God knows best.

\section{Conclusion}

From the explanation above, some notes can be drawn as conclusions. The efforts / strategies carried out by the people in Surakarta in maintaining the Javanese language as the main means of communication in their social life in the current pandemic era are as follows:

1) Using the education pathway strategy (formal and non-formal). Education is still believed to be one of the most effective strategies to defend the Javanese language in the midst of the onslaught and siege of the global world and language politics policies that tend to prioritize Indonesian;

2) Through the family environment, namely by using Javanese in interacting with husband/wife and children, although not all families use Javanese as their daily language;

3) Through the example of community leaders and/or parents (Basa Tulodho);

4) By continuing to use and teach Javanese to the next generation;

5) Through culture, especially the arts, such as Karawitan, Gamelan, etc.;

6) Through competitions, such as Geguritan, Macapatan, Kirab Budaya (Cultural Carnival) competitions;

7) Through radio (RRI) and/or television (MTA TV, Solo TV, TA TV) by presenting Klenengan and cultural programs;

8) Through book literacy in the Javanese language;

9) Through art trainings, such as dance, Pranotocoro, Atur Pambagyo, Klenengan, etc.;

10) Through policies and or programs from the government (Department of Culture and Tourism).

11) The 10 Javanese language defence strategies that have been carried out by the people in Surakarta, especially in Jayasuran Village, Pasar Kliwon District, are constrained by the Covid-19 pandemic situation, which is still ongoing now

\section{References}

1. Budiarta, I Wayan, Eksistensi Bahasa Loka Terkait Pemindahan Ibu Kota Negara Ke Kalimantan Timur: Ancaman dan Strategi Pemertahanannya, Prosiding Seminar Nasional Program Pascasarjana Universitas Marwadewa kerjaa sama dengan Program Pascasarjana Universitas Mulawarman, (2019)

2. Hardjowirogo, Marbangun, Manusia Jawa, Jakarta: Haji Masagung, (1994). 
3. Purwoko, Herudjati, Muatan Budaya, Sosial dan Politik dalam Bahasa dan Komunikasi, Yogyakarta: Graha Ilmu, (2014)

4. Rahyono, Kearifan Budaya dalam Kata, Jakarta: Wedatama Widya Sastra, (2009)

5. Rokhman, Fathur dan Surahmat, Linguistik Disruptif: Pendekatan Kekinian Memahami Perkembangan Bahasa, Jakarta: Bumi Aksara, (2020)

6. Sibarani, Robert, Antropolinguistik, Medan: Penerbit Poda, (2004)

7. Suharyo, Nasib Bahasa Jawa dan Bahasa Indonesia dalam Pandangan dan Sikap Bahasa Generasi Muda Jawa, dalam Jurnal Nusa, Vol.13, No.2, 2018, p.244-255

8. Supeno, Hadi, Manusia Jawa Modern, Banjarnegara: @ktor Publishing, (2019)

9. Suratminto, Lilie, dkk. Kepunahan Bahasa: Bahasa Kreol Tugu yang Punah dalam Pemertahanan Budaya Tugu, Jakarta: Laboratorium Leksikologi dan Leksikografi, Departemen Linguistik, Fakultas Ilmu Budaya, Universitas Indonesia, (2016) 